\title{
ДОСУДЕБНЫЕ МЕРОПРИЯТИЯ ПО ПРЕДОТВРАЩЕНИЮ НЕСОСТОЯТЕЛЬНОСТИ
}

\author{
(c) 2019 Ибрагимов Юсуп Муслимович \\ ассистент кафедры теории и технологии социальной работы \\ Чеченский государственный университет, Чеченская Республика, Грозный \\ E-mail: yusuf_ibr@mail.ru
}

Анализируются отдельные положения Закона о банкротстве, посвященные досудебным мерам по предупреждению банкротства. Рассмотрена проблема осуществления мер по предупреждению банкротства. Отмечается, что на сегодняшний день мероприятия, направленные на предупреждение банкротства, должны способствовать главным образом повышению платежеспособности должника.

Ключевые слова: Банкротство, Закон о банкротстве, должник, кредитор, меры по предупреждению банкротства, долг, несостоятельность.

Вторая глава Закона о банкротстве регламентирует непосредственно вопросы, связанные с предотвращением банкротства, и согласно ее положениям, «появление у должника признаков банкротства влечет за собой обязанность руководителя должника направить сведения о наличии признаков банкротства, в том числе о размере, структуре, возможности погашения задолженности» [2], «учредителям должника, собственнику имущества должника - унитарного предприятия, которые обязаны применить своевременные меры с целью предупреждения банкротства организаций» [5]. Такие меры могут быть приняты кредиторами или другими лицами на основании соглашения с должником.

Также, как пишет Телюкина М.В., в правовой науке и судебно-арбитражной практике можно встретить подход, в соответствии с которым Закон о банкротстве не включает в себя такие правовые последствия как санкции в ситуациях неисполнения руководителем должника обозначенной выше обязанности [6].

Кроме того, такая позиция не соответствует и положениям ст. 10 Закона о банкротстве. Например, в случаях нарушения руководителем должника или учредителем должника, собственником имущества должника - унитарного предприятия, членами органов управления должника, членами ликвидационной комиссии (ликвидатором), гражданином-должником положений данного Закона перечисленные лица несут обязанность возмещения убытков, причиненных в ходе данного нарушения. Нельзя назвать исключением и нарушение руководителем должника обязанности, закрепленной п. 1 ст. 30 Закона о банкротстве, в случае которого последний обязан возместить убытки, причиненные в ходе данного нарушения [2].

В число мер по предупреждению банкротства должника необходимо включить и предоставление финансовой помощи в том размере, который является достаточным для погашения денежных обязательств и обязательных платежей, а также восстановления платежеспособности должника. Такое предоставление финансовой помощи может дополняться принятием на себя должником или другими лицами обязательств в пользу лиц, которые и предоставили финансовую помощь, о чем пишут в своем исследовании Зинченко С.А. и Гончаров А.И [1].

Меры по предупреждению банкротства организаций и санация не закреплены в ст. 27 Закона о банкротстве в качестве процедур, используемых в делах о банкротстве, тем не менее, учитывая содержание и значение обозначенных мер, необходимо отметить, что такие меры, по своей сути, являются процедурами, направленными на предупреждение банкротства. Независимо от того факта, что суд еще не принял заявление о признании должника банкротом, не возбудил производство по делу о банкротстве, лица, заинтересованные в восстановлении платежеспособности должника принимают определенные меры, фактически, осуществляется процедура предупреждения банкротства. Таким образом, как по мнению Свит Ю., так и на наш взгляд, есть все основания для того, чтобы считать обозначенные действия специальной 
процедурой банкротства [4]. Учитывая данный факт, законодательству о банкротстве требуется совершенствование системы мер и процедур предупреждения банкротства с целью стимулирования заинтересованности субъектов гражданского оборота принимать целесообразные и рациональные действия, направленные на восстановление платежеспособности и предотвращение банкротства.

Помимо прочего, существует необходимость в разработке и внесении в законодательство норм о проведении мероприятий, связанных с предупреждением банкротства должника.

На данный момент положения ст. ст. 30 и 31 Закона о банкротстве, регламентирующие предупреждение банкротства, имеют скорее декларативный характер и, по мнению многих ученых, «скорее, выражают благие пожелания, нежели закрепляют реально работающий механизм» [7]. И действительно, на практике данные меры сводятся к предложению собственникам или другим лицам предоставить должнику нужную сумму с той целью, чтобы последний получил возможность рассчитаться со своими кредиторами. Отсутствует как механизм принятия решений, так и механизм защиты интересов предполагаемых инвесторов, так и гарантии дальнейшего исполнения обязательств со стороны кредиторов должника. Даже в тех случаях, когда собственники компании готовы погасить требования кредиторов, суды не дают возможности сделать им это.

Например, в одном из случаев, участник компании-должника предпринял попытку погасить требование данного кредитора. Участник перечислил денежные средства на единственный расчетный счет кредитора, однако счет оказался закрытым и деньги были ему возвращены. В ходе судебного разбирательства участник выразил свою готовность погасить требования кредитора с целью недопущения банкротства. Было доказано и действительное наличие денег, и реальность попытки погасить долг, и отсутствие у кредитора счетов. Тем не менее, сам кредитор сказал, что не имеет заинтересованности в получении денег и ставит своей целью обанкротить должника, в связи с чем и закрыл счет.

Независимо от того факта, что самым разумным и защищающим интересы кредитора является получение требуемой им суммы, суд решил занять позицию, в соответствии с которой преимущество было отдано желанию кредитора ввести процедуру банкротства, а не желанию получить деньги. В конечном итоге должник был обанкрочен [3].

Учитывая вышеописанные факты можно заметить, что в законодательстве о банкротстве необходимо предусмотреть более широкие последствия такой меры, как санация предприятия, а также более конкретно определить порядок проведения последней. Сообщение о начале санации компании должно быть зафиксировано в официальных источниках и, соответственно, опубликовано. Закрепление факта начала санации возможно и в регистрирующих органах, или же сообщение о санации подается в суд, который в результате ее безуспешности будет рассматривать дело о банкротстве должника.

Нельзя не учитывать, что в случае объявления о проведении санации должника наступает ряд последствий, зачастую аналогичный последствиям начала процедуры ликвидации компании. Требуется приостановить работу всех исполнительных производств, разблокировать счета, ввести мораторий на расчеты с кредиторами.

Уже после выполнения данных требований должнику дается возможность составить план выхода из сложившейся ситуации или же подготовить мировое соглашение. И первый и второй должны быть представлены на ознакомление кредиторам должника. Состав самих кредиторов в такой ситуации необходимо определять исходя из тех же правил, что и в рамках процедуры ликвидации, разумеется, выражая их требования не в промежуточном ликвидационном балансе, а в любом другом реестре заявленных требований.

Кредиторы должника, а главным образом те, права которых обеспечиваются залогом имущества должника, имеют возможность принять или не принять составленный должником план вывода компании из кризиса, а также и мировое соглашение. Порядок их утверждения по своей сути тождественен правилам заключения мирового соглашения в случае банкротства. Другими словами, он должен быть принят большинством голосов с непреложным условием, что каждый залоговый кредитор высказался за его утверждение. План может включать в себя самые разнообразные способы расчетов с кредиторами должника. В частности, это могут быть рассрочка погашения долга, списание части долгов, реорганизация компании и так далее.

Разумеется, санация имеет предельный 
срок проведения. Срок, в который ее необходимо провести, составляет шесть месяцев, в течение которых должен быть утвержден план выхода из кризиса или же заключено мировое соглашение. Продление срока санации возможно осуществить только по решению кредиторов должника. В том случае, если кредиторы не собираются поддерживать должника в его плане выхода из кризиса либо предложенный им план их не устраивает, процедуру санации вряд ли удастся затянуть.

Тем не менее, даже в случае неудачного проведения санации положительным моментом можно будет считать тот факт, что должник получит дополнительное время для решения сложившихся проблем. Довольно часто должники оказываются банкротами только потому, что не смогли грамотно рассчитать время необходимое на осуществление того или иного плана. В частности, не успели получить кредит или договориться обо всех аспектах сделки, как например, в недавнем случае со сделкой с сетью «Связной», когда задержка в заключении контракта с «МТС» обернулась просрочкой по погашению кредита в пользу группы «ОНЭКСИМ» и последовавшей за этим передачей в качестве отступного группе «ОНЭКСИМ» розничной сети «Связной» [8].

Возможность дополнительного времени для выхода из кризиса посредством процедуры са- нации, а также и преодоление кризиса подобным способом позволит уменьшить количество банкротств должников, что, в свою очередь уменьшит отрицательное влияние на экономику. Более того, введение процесса санации послужит еще одним стимулом для субъектов гражданского оборота к решению возникающих проблем мирным способом, а не в рамках судебного производства.

Важно сказать, что процедура банкротства должна главным образом преследовать цели оздоровления экономики, а не уничтожения коммерческой структуры с последующим за ним делением между кредиторами денежных средств, которые можно получить от продажи активов должника. Задачей института банкротства является обеспечение сохранения производственного, интеллектуального и бизнес-потенциала, а также осуществление наиболее безболезненного перехода производства в руки иного лица. Таким образом, если подобная возможность будет доступна не только в процессе процедуры банкротства, но также и в результате мер, предшествующих банкротству, это позволит обеспечить наибольшую сохранность имущества должников, скорейший переход их в другие руки и сохранение стоимости бизнеса должника. Данные факты, так или иначе, окажут положительное влияние на экономику страны в целом.

\section{Библиографический список}

1. Зинченко С.А., Гончаров А.И. Предупреждение банкротства коммерческой организации: методология и правовые механизмы. М.: Юриспруденция, 2006. С. 114.

2. Научно-практический комментарий (постатейный) к Федеральному закону «О несостоятельности (банкротстве)» / Под ред. д-ра юрид. наук, проф. В.В. Витрянского. М.: Статут, 2004. С. 225-226

3. Определение Семнадцатого арбитражного апелляционного суда от 09.04.2015 по делу № A60-56117/2014 о банкротстве ООО «Научно-производственное предприятие «Ресурс» // СПС Гарант

4. Свит Ю. Восстановительные процедуры - способ предотвращения банкротства // Российская юстиция. 1998. № 3

5. Телюкина М.В. Основы конкурсного права. М.: Волтерс Клувер, 2004. С. 262-265.

6. Телюкина М.В. Указ. соч. С. 262; Постановление ФАС Центрального округа от 30.09 .2005 по делу № A145278-2005/39/20б // СПС Гарант.

7. Филиппов А.С. Банкротство ликвидируемого должника: как это работает // Вестник экономического правосудия РФ. 2015. № 6. С. 40

8. http://www.kommersant.ru/doc/2634976 